DOI: https://doi.org/10.15407/techned2018.04 $: \underline{010}$

\title{
ANALYTICAL AND NUMERICAL DETERMINATION OF THREE-DIMENSIONAL QUASI-STATIONARY ELECTROMAGNETIC FIELD OF ALTERNATING CURRENT CONTOUR NEAR THE CONDUCTING MEDIUM
}

Journal

Publisher

ISSN

Issue

Pages
Tekhnichna elektrodynamika Institute of Electrodynamics National Academy of Science of Ukraine 1607-7970 (print), 2218-1903 (online)

No 4, 2018 (July/August)

$10-13$

\section{Authors}

Yu.M. Vasetsky ${ }^{\star}$, I.M. Kucheriava, I.L. Mazurenko**, K.K. Dziuba Institute of Electrodynamics National Academy of Sciences of Ukraine, pr. Peremohy, 56, Kyiv, 03057, Ukraine, e-mail: yuriy.vasetsky@gmail.com

* ORCID ID : http://orcid.org/0000-0002-4738-9872

** ORCID ID : http://orcid.org/0000-0002-0146-7396

\begin{abstract}
The distributions of three-dimensional quasi-stationary electromagnetic field formed in the system of "spatial contour with alternating current - conducting half-space" are analyzed. The calculations are carried out by two ways: analytically and numerically using program Comsol. The obtained data are in agreement with each other. They verify the theoretical result about zero normal components of electric field strength and current density in the conducting half-space. References 3, figures 5.
\end{abstract}


Key words: three-dimensional electromagnetic field, eddy current, numerical and analytical methods.

Received: 02.03 .2018

Accepted: 14.03.2018

Published:

\section{References}

1. Kondratenko I.P., Rashchepkin A.P. Induction heating of moving strip current contours. Tekh nichna Elektrodynamika

1999. No 3. Pp. 3-9. (Rus)

2. Rudnev V., Loveless D., Cook R., Black M. Handbook of induction heating. Marcel Dekker Inc., 2003. $777 \mathrm{p}$.

3. Vasetsky Yu.M., Dziuba K.K. An analytical calculation method of quasi-stationary three-dimensional electromagnetic field created by the arbitrary current contour that located near conducting body. Tekhnichna Elektrodynamika. 2017. No 5. Pp. 7-17. (Rus) DOI: https:// doi.org/10.15407/techned2017.05.007

$\underline{\text { PDF }}$ 